\title{
Kesenian Hadrah Sebagai Warisan Budaya Di Kota Pontianak Kalimantan Barat
}

\author{
Regaria Tindarika ${ }^{1}$, Iwan Ramadhan ${ }^{2}$ \\ ${ }^{12}$ Fakultas Keguruan dan Ilmu Pendidikan Universitas Tanjungpura \\ regaria.tindarika@fkip.untan.ac.id, iwan.ramadhan@untan.ac.id
}

\author{
Received: 17 March 2021; Revised: 16 June 2021; Accepted: 28 August 2021 \\ DOI: http://dx.doi.org/10.37905/aksara.7.3.907-926.2021
}

\begin{abstract}
Abstrak
Kesenian Hadrah telah menjadi kesenian yang di bawakan dalam beberapa acara yang ruang lingkupnya kecil yang dilakukan oleh kepala keluarga hingga besar seperti perlombaan tingkat provinsi. Oleh karena itu peneliti tertarik mengetahui lebih lanjut keberadaan seni hadrah sebagai warisan budaya di kota Pontianak, Kalimantan Barat. Metode yang dipakai adalah kualitatif deskriptif serta penelitian ini dilakukan dibantu dengan teknik pengumpulan data berupa wawancara kepada narasumber, pengamatan secara langsung dan studi dokumentasi. Dalam mengalisis hasil data, menggunakan suatu pendekatan historis dan antropologis. Setelah dilakukan penganaisisan, didapatkan data bahwa Seni Hadrah mengalami beberapa kali kemunduran dari awal kedatangannya di Kota Pontianak hingga sekarang. Walaupun sempat mengalami kemunduran pada masa penjajahan Jepang, akan tetapi masih terus dipertahankan dan ditampilkan di Kota Pontianak hingga sekarang. Hal ini dibuktikan dengan masih bertahannya grup kesenian Hadrah di Pontianak yang biasanya tampil pada saat peringatan Maulid Nabi, khitanan, pesta nikah dan aqiqah. Penelitian ini diharapkan dapat meningkatkan rasa cinta dan kepedulian kepada generasi muda, sehingga dapat melestarikan serta menjaga potensi budaya yang dimiliki melalui nilai-nilai khususnya nilai-nilai agama Islam yang terkandung dalam seni Hadrah.
\end{abstract}

Kata Kunci : Kesenian, Hadrah, Warisan Budaya

\begin{abstract}
Hadrah art has become an art presented in several small-scale events carried out by family heads to large ones such as provincial level competitions. Therefore, researchers are interested in knowing more about the existence of hadrah art as a cultural heritage in the city of Pontianak, West Kalimantan. The method used is descriptive qualitative. This research was carried out with the help of data collection techniques in the form of interviews with informants, direct observation, and documentation studies. In analyzing the results of the data, using historical and anthropological approaches. After being analyzed, it turns out that Seni Hadrah has experienced several setbacks since its initial arrival in Pontianak City until now. Although it had experienced a setback during the Japanese colonial period, it was still maintained and displayed in the city of Pontianak. This is evidenced by the persistence of the Hadrah art group in Pontianak, which usually performs at the commemoration of the Prophet's Birthday, circumcision, weddings, and aqiqah. This research is expected to increase the love and concern of the younger generation to preserve and maintain their cultural potential through values, especially Islamic religious values contained in the art of Hadrah.
\end{abstract}

Keywords : Art, Hadrah, Cultural Heritage 


\section{PENDAHULUAN}

Kalimantan Barat merupakan wilayah yang dekat dengan negara tetangga yaitu Malaysia, yang terbentang dari wilayah bagian Serawak dan sampai dengan adalah Laut Natuna, Selat Karimata serta Semenanjung Malaysia, (Daud, Shahrul, and Abd 2019). Kalimantan Barat (KalBar) merupakan salah satu provinsi yang yang berada di pulau Kalimantan serta terdapat 12 kabupaten dan 2 kota, satu diantaranya adalah Kota Pontianak.

Kota Pontianak dikenal dengan kota khatulistiwa karena di terletak tepat dibawah garis Khatulistiwa. Dilihat dari posisinya, disebelah Barat Kota Pontianak merupakan wilayah pesisir karena terdapat selat, semenanjung bahkan laut. Sebagai wilayah pesisir, Pontianak sangat mudah di akses serta menjadi daerah bertemunya beraneka ragam kebudayaan karena pada zaman dahulu, wilayah ini menjadi tempat berlabuhnya kapalkapal pedagang baik dari Tionghoa, India, Yaman dan Arab, (Madjid 2018). Para pedagang ini tidak hanya berdagang saja, akan tetapi membawa serta kebudayaan yang mereka miliki. Adanya kekuatan dari suatu budaya tentunya didukung dengan pemberdayaan dari masyarakat atau kepedulian yang menjadi aspek pembentukan penilaian dalam kemanusiaan, (Hemafitria and Yuliananingsih 2020).

Menurut (Jazuli 2014), Masyarakat adalah orang yang tinggal dalam wilayah tertentu dan memiliki interaksi serta berhubungan satu dengan yang lain. Kemudian masyarakat ini memiliki sebuah kebudayaan. Kebudayaan merupakan seluruh tindakan manusia dalam kehidupan masyarakat yang di biasakan dengan belajar. Kebudayaan itu sendiri lahir dari akal budi, jiwa atau hati nurani manusia ((Koentjaraningrat 2015). Kebudayaan-kebudayaan ini kemudian memberikan pengaruh kepada kebudayaan yang ada di Pontianak, melebur dan berakulturasi. Dari proses tersebut lahirlah kebudayaan baru yang melebur atau berakulturasi tetapi kebudayaan asli mereka masih tetap ada/terlihat. Hal inilah yang menyebabkan begitu banyak kebudayaan yang dimiliki oleh Kota Pontianak. Memiliki budaya yang cukup banyak di sebabkan karena keanekaragaman suku yang ada di Kota Pontianak. Suku-suku besar yang ada di Pontianak adalah, Melayu, Dayak, dan Tionghoa. Tiap-tiap suku memiliki kebudayaannya masing-masing. Satu diantara bentuk kebudayaan tersebut adalah kesenian. Seperti yang dikemukakan oleh (Koentjaraningrat 2015), kesenian merupakan satu dari dari tujuh unsur kebudayaan universal.

Dalam kehidupan sehari-hari, masyarakat berhubungan erat dengan kesenian. Hal ini terlihat jelas pada setiap kegiatan atau pelaksanaan acara di masyarakat, biasanya suatu kesenian yang juga ikut digelar. Kesenian menjadi gambaran serta identitas dari budaya setempat. Kesenian tidak hanya sekedar karya belaka, melainkan kesenian juga bisa membentuk kepribadian bagi para pelaku dan penikmat kesenian. Berbagai macam bentuk kesenian telah hidup subur di dalam masyarakat. Kesenian tersebut banyak jenisnya, ada yang berupa tari, musik, rupa dan teater. Pontianak memiliki banyak kesenian, seperti lantunan syair, tari tradisional, kain dan corak khas, serta upacara tradisional, (Batubara 2017). Adapun kesenian yang dimiliki oleh kota Pontianak serta menjadi fokus dalam penelitian ini adalah Kesenian Hadrah.

Kesenian Hadrah mendapat pengaruh dari pedagang-pedagang Yaman yang datang ke Kota Pontianak. Hadrah sendiri, berasal dari dzikir dengan lantunan-lantunan syair berbahasa Arab berisi tentang pujian-pujian kepada Allah Subhanahu Wa Ta'ala dan Nabi Muhammad Shallallahu Alaihi Wasallam. Lantunan syair ini tidak hanya 
tentang pujian pujian kepada Allah Subhanahu Wa Ta'ala dan Nabi Muhammad Shallallahu Alaihi Wasallam, tetapi juga berisi tentang perintah dan larangan-Nya. Hal ini menjadikan Hadrah sebagai media penyebaran agama Islam oleh pedagang pedagang Yaman di kota Pontianak. Penyebaran agama Islam dengan media kesenian Hadrah ini mengakibatkan masyarakat sekitar mudah menerimanya.

Menurut penuturan Anwar Ja'far (48), kesenian Hadrah ini muncul pada tahun 17an di era Kerajaan Kesultanan Pontianak Kalimantan Barat. Kemudian berkembang hingga abad 19-an dan menyebar hingga ke berbagai daerah yang ada di wilayah Kalimantan Barat. Pada awal mula kemunculan kesenian ini, Hadrah di bawakan secara beramai-ramai oleh ulama dan warga sekitar di dalam masjid. Seiiring berjalannya waktu, kesenian ini semakin diminati, sehingga menjadi acara hiburan setelah melakukan hajatan (malam terakhir hajatan) tepatnya selesai sholat Isya. Kesenian Hadrah masih tetap bertahan dan eksis serta dilaksanakan secara rutin oleh warga kota pontianak dan sekitarnya, umumnya masyarakat Kalimantan Barat. Pelaksanaan ini dapat kita jumpai pada sebuah ajang perlombaan yang dilaksanakan oleh MABM (Majelis Adat Budaya Melayu) menjadikan kesenian ini satu diantara ajang perlombaan Tangkai Melayu di Kota Pontianak Kalimantan Barat.

Pada mulanya kesenian Hadrah hanya di sajikan dengan posisi duduk bersila sambil memainkan alat musik tar dan bersyair dalam bahasa Arab sambil memuji memuja keEsaan Allah serta nabi-Nya, (Tindarika 2021). Kesenian Hadrah diiringi dengan alat musik tar. Pemain tar dalam kesenian ini terdiri dari 3 (tiga) orang. Ada yang bertugas sebagai penabuh induk dan yang lain menjadi penabuh ningkak (mengisi tabuhan dari penabuh induk). Alat musik tar ini sendiri adalah hasil akulturasi dari alat musik yang berasal dari Yaman dan Pontianak. Awalnya ukuran alat musik ini lebih besar dari tar yang ada sekarang. Tar yang berkembang hingga sekarang berdiameter lebih kurang 30-40cm. Kemudian syair dalam kesenian ini diganti dengan bahasa Indonesia oleh seorang seniman bernama Haji Muhammad. Beliau meriwayatkan kisah Nabi Muhammad shallallahu alaihi wasallam dan ke-Esaan Allah Subhanahu Wa Ta'ala dalam bahasa Indonesia agar mudah dimengerti oleh masyarakat setempat. Beliau memanfaatkan keahliannya untuk menyampaikan nilai-nilai ajaran agama Islam dan hal ini diteruskan oleh keturunannya serta seniman-seniman lain di Kota Pontianak.

Kemudian pada tahun 1970an kesenian ini berkembang dengan menambahkan gerakan yang mewakili dari syairnya. Gerakan tersebut terinspirasi dari gerak wudhu, sholat dan azan. Menurut (Meri 1986) gerak adalah bagian atau unsur terpenting dari tari dan dapat di katakan bahwa tari adalah bergerak. Gerakan-gerakan tersebut membentuk tarian yang dinamai Tari Radat Hadrah. Menurut Akan tetapi tari Radat Hadrah tidak seeksis kesenian Hadrah. Hal ini di tandai dengan beberapa perkumpulan atau grup kesenian Hadrah hanya latihan tari Radat jika ada perlombaan saja. Menurut penuturan Anwar Ja'far, tari ini juga jarang diminta untuk tampil pada acara hajatan.

Melihat pasang surut keberadaan kesenian ini, maka peneliti menjadikan fokus penelitian kepada eksistensi kesenian Hadrah yang merupakan satu diantara warisan budaya di kota Pontianak. Mengingat banyak faktor yang melatarbelakangi keberadaan kesenian ini di Pontianak, dari awal kemunculannya hingga sekarang. Lebih lanjut di dalam penelitian ini berfokus kepada keberadaan kesenian ini, serta faktor pendukung dan penghambat yang mempengaruhinya. Berdasarkan penjabaran tersebut, maka judul penelitian ini adalah "Kesenian Hadrah Sebagai Warisan Budaya di Kota Pontianak". 
Adapun terdapat masalah penelitian yang menjadi pijakan awal peneliti dalam menganalisis keberadaan kesenian Hadrah sebagai warisan budaya di kota Pontianak serta faktor yang mendukung dan menghambatnya. Untuk membedahnya digunakan teori yang berkaitan dengan eksistensi, kesenian, Hadrah, serta warisan budaya. Dari paparan tersebut untuk menjawab guna menjawab masalah yang ada pada hasil penelitian nantinya diperlukan tujuan penelitian yaitu: "Mendeskripsikan keberadaan kesenian Hadrah sebagai warisan budaya di Kota Pontianak", serta "mendeskripsikan faktor yang mempengaruhi keberadaan dari kesenian Hadrah di Kalimantan Barat, khususnya Pontianak".

\section{METODE PENELITIAN}

Metode penelitian deskriptif di gunakan dalam rangka menjabarkan informasi yang didapat terkait penelitian yang dilakukan. Hal tersebut sesuai dengan pendapat dari (Ary, Donal, Luchy Cheser Jacobs 2011), bahwa penelitian deskriptif dibuat untuk memperoleh fakta mengenai status dari tanda-tanda dalam waktu penelitian dilakukan.

Pendapat tersebut sejalan dengan yang diutarakan oleh Furchan bahwa metode deskriptif memiliki tujuan, yaitu mengilustrasikan aspek atau keadaan yang terjadi apa adanya, karena penelitian ini bukan untuk menguji hipotesis, melaikan mencari informasi yang dapat digunakan dalam mengambil keputusan. Pendapat tersebut sejalan dengan (Sugiyono 2018), yang memaparkan bahwa metode deskriptif tidak hanya sekedar untuk menganalisis data saja, akan tetapi data yang telah di dapatkan sebelumnya diinterpretasikan, menguraikan dan menjabarkan sehingga mendapatkan kesimpulan yang bersifat umum atau general. Adapun maksud dari interpretasi seperti yang dikemukakan di atas adalah cara berpikir dengan memahami dan kemampuan analisa dari peneliti, yang dituangkan ke dalam teori-teori yang memperkuatnya.

Dari kedua pendapat tersebut dapat di temukan bahwa tujuan dari penelitian deskriptif adalah mengandalkan kemampuan peneliti untuk dapat menganalisa dengan cara membuat gambaran, paparan, lukisan atau jabaran data secara terstruktur, konkret dan akurat mengenai kenyataan (fakta) serta berbagai hubungan antar gejala yang diselidiki. Alasan digunakan metode deskriptif dalam penelitian ini adalah peneliti melakukan pengamaan langsung dan hanya mendeskripsikan situasi tentang keberadaan kesenian Hadrah sebagai warissan budaya di Kota Pontianak.

Penelitian ini menggunakan payung historis dan antropologi. Adapun penelitian sejarah atau historical reseach merupakan suatu penelitian yang bersifat sistematis dengan data-data atau sumber yang dapat dipercayai dengan lingkup pertanyaanpertanyaan yang dilakukan oleh sejarahwan di masa sebelumnya. Sedangkan menurut pendapat lainnya, penelitian sejarah merupakan salah satu proses penelitian yang dilakukan secara kritis dengan mengedepankan peristiwa masa lampau dengan tujuan untuk mendeskripsikan serta menafsirkan penemuan secara terperinci dan akurat mengenai kejadian-kejadian yang didapat, (Djamal 2015).

Menurut Suyono (Nurmansyah, Gunsu, Nunung Rodliyah 2019) Antropologi adalah ilmu yang memperlajari tentang manusia. Adapun yang dipelajari adalah sifatsifat manusia berdasarkan bentuk fisik, kepribadian, masyarakat, serta kebudayaannya. Sejalan dengan pendapat tersebut (Koentjaraningrat 2015), mendefinikan antropologi sebagai ilmu yang mempelajrai manusia dari keanekaragaman bentuk fisiknya, masyarakat, serta kebudayaanya. 
Meotde penelitian yang digunakan adalah deskriptif. Menurut (Ary, Donal, Luchy Cheser Jacobs 2011), penelitian deskriptif dirancang untuk mendapatkan suatu penemuan yang berkaitan dengan gejala atau fenomena yang didapatkan pada saat penelitian dilaksanakan sehingga dapat digunakan dalam pengambilan keputusan. Pendapat tersebut diperkuat oleh (Sugiyono 2009), bahwa metode deskriptif adalah pengumpulan data-data yang didapat dengan apa adanya sesuai dengan kaidah penelitian yang disusun, diproses serta dianalisis secara seksama guna mendapatkan gambaran atau pendeskripsian terkait dengan acuan indikator yang telah ada sebelumnya.

Untuk memperkuat pada penelitian ini, dilakukan teknik agar dapat mengumpulkan data secara akurat yaitu dengan melakukan pengamatan yang lebih mendalam, melakukan tanya jawab kepada informan yang telah dipilih berdasarkan kriteria yang telah ditentukan sebelumnya, melakukan dokumentasi serta melakukan studi mendetail terhadap hasil dengan teori yang digunakan. Adapun yang menjadi narasumber pada penelitian ini adalah Anwar Jakfar (47), beliau adalah seniman hadrah, pemain hadrah pada grup Hadrah Hubbul Wathon di daerah Sungai Jawi, dan Ustad Ma'arif Muhammad Arif (68) beliau adalah tokoh Hadrah senior di Kota Pontianak. Sementara dilapangan teknik pengumpulan dengan wawancara yaitu dengan pertanyaan yang semi terstruktur.) Wawancara semi terstruktur merupakan salah satu jenis tanyajawab yang dikategorikan pada in-dept interview. Yaitu dilaksanakan dengan lebih leluasa atau bebas dibandingkan dengan wawancara secara terstruktur. Dengan menggunakan wawancara ini bertujuan guna mendapatkan hasil sesuai dengan permasalahan yang lebih relevan, serta informan dapat mengeluarkan informasiinformasi yang lebih detail dan sesuai dengan apa yang diingin oleh peneliti, (Sugiyono 2015).

Penelitian ini dilakukan dengan wawancara kepada informan dan dengan seksama mendengarkan, menelaah serta merekam apa yang telah dibicarakan oleh informan secara lebih detail, yang peneliti lakukan melalui dua hal yaitu menemui informan secara langsung (tatap muka) yang kedua dengan melakukan wawancara via telepon.

Informasi yang berhasil peneliti dapatkan dari hasil wawancara tersebut peneliti kombinasikan dengan data lain dari referensi-referensi yang relevan dan sesuai dengan tujuan dari penelitian yang berkaitan dengan Kesenian Hadrah guna menunjang penelitian ini menjadi penelitian yang mendalam, kemudian peneliti susun.

Setelah data terkumpul kemudian diuji kebenaran atau kevalidan data tersebut menggunakan teknik penguji keabsahan data melalui perpanjang pengamatan dan triangulasi sumber. Kemudian dalam menguji keabsahan data yang didapatkan peneliti melakukan penyajian dalam bentuk laporan yang sesuai dengan gaya selingkung yang telah ada, hal ini dilaukan agar dipertangung jawabkan dengan kaidah yang telah ditentukan. Perpanjangan pengamatan menurut (Sugiyono 2018), adalah melakukan pengecekan data dengan kembali ke lokasi penelitian untuk melaksanakan observasi serta mewawancarai informan kembali agar mendapatkan data hasil penelitian yang lebih detail dan akurat yaitu dengan menemui informan sebelumnya atau bahkan menambah informan yang baru. Perpanjangan pengamatan disini adalah bertujuan menjalin keakraban antara peneliti dan narasumber atau informan sehingga diharapkan hasil yang dapat sesuai dengan yang diinginkan dan menjalin keakraban secara terbuka 
serta saling menghormati dan menghargai dan hasil akhirnya informasi yang didapat sudah maksimal dan sudah sesuai dengan yang diharapakan.

Uji keabsahan data selanjutnya adalah triangulasi, khususnya triangulasi sumber. Menurut (Sugiyono 2018), demi mengecek data yang kreadibel dilakukanlah triangulasi data yang telah didapat dari berbagai narasumber sebelumnya, kemudian sebelumnya dari berbagai narasumber dianalisis serta disimpulkan, dan diakhir adalah memberikan persetujuan atas kesepakatan dengan data-data yang telah didapat sebelumnyya. Peneliti melakukan pengecekan data dengan membandingkan data yang diperoleh dari Anwar Ja'far dan Ma'arif Muhammad Arif, kemudian ditarik kesimpulan dari data yang didapat sehingga didapatkan data yang valid.

Sedangkan peneliti menganalisis data yang didapat yang dengan mengorganisasikan data-data tersebut, memilah dan mililih mana saja yang data yang merupakan data akurat atau pending kemudian akan dipelajari sesuai aturan analisis penelitian yang ada. Terakhir, data yang terkumpul nantinya akan dianalisis serta dilakukan pengklasifikasian agar mendapatkan data yang lebih rapi dan tersusun secara sistematis, sehingga nantinya akan mudah ditelaah lebih mendalam dan menghasilkan data yang sesuai dengan harapan atau tujuan penelitian.

\section{HASIL DAN PEMBAHASAN}

Dalam menelusuri dan mencari informasi yang akurat tentang eksistensi Kesenian Hadrah di Kota Pontianak peneliti menemui beberapa narasumber yang kompeten dalam memberikan informasi tentang Kesenian Hadrah. Pertama kali peneliti bertemu dengan narasumber Anwar Ja'far (47) di tempat kerjanya yaitu kampus 2 Prodi Pendidikan Seni Pertunjukan UNTAN dan Ustad Ma'arif/Muhammad Arif (68), wawancara dilakukan di rumah beliau berada di jalan Parit Pangeran, siantan kota Pontianak. Dari kegiatan pengumpulan data kemudian dianalisis dan dijabarkan.

Hadrah sangat erat kaitannya dengan agama Islam. Oleh karena itu kesenian Hadrah menjadi sebuah kesenian yang bernafaskan Islam. Hal tersebut dikarenakan kesenian Hadrah berasal dari Hadramaut Semenanjung Arab, Yaman Selatan. Sejarah masuknya Hadrah di Kota Pontianak bersamaan dengan masuknya Agama Islam di Pontianak, diperkirakan sekitar tahun $1741 \mathrm{M}$. Ulama yang pertama kali membawa Islam ke Kalimantan Barat adalah Syarief Husein Al Kadri, beliau lahir tahun $1118 \mathrm{H} \mathrm{di}$ Trim Hadramat Yaman Selatan Semenanjung Arab.

Satu diantara strategi dakwah Beliau dalam mendakwahkan Islam baik Sultan Syarief Husein al Kadri maupun putranya Sultan Syarief Abdurrahman Al Kadri adalah melalui media seni yaitu seni Dzikir. Seni Dzikir berisi Syair-syair/ Qasidah yang memuji Kebesaran Alloh dan mengagungkan Nabi Muhammad SAW, syair tersebut diambil dari Kitab Maulud.

Kitab Maulud yang popular dan sering dibaca dalam perayaan Maulid di Indonesia ada 4 yaitu

1) Kitab Maulud Habsyi atau Simtut Dhuror dikarang oleh Al-Habib Al-Imam AlAllamah Ali bin Muhammad bin Husin Al-Habsyi

2) Kitab Maulud Dhiba' dikarang oleh Imam Wajihuddin 'Abdur Rahman bin Muhammad bin 'Umar bin 'Ali bin Yusuf bin Ahmad bin 'Umar ad-Diba'ie asySyaibani al-Yamani az-Zabidi asy-Syafi'I

3) Kitab Barzanji dikarang oleh Sayyid Ja'far Al-Barzanji, 
4) Kitab Maulud Burdah dikarang oleh Syarafuddin Abu Abdillah Muhammad bin Zaid al-Bushiri,

Berikut ini merupakan gambar dari kitab Maulud Habsyi.

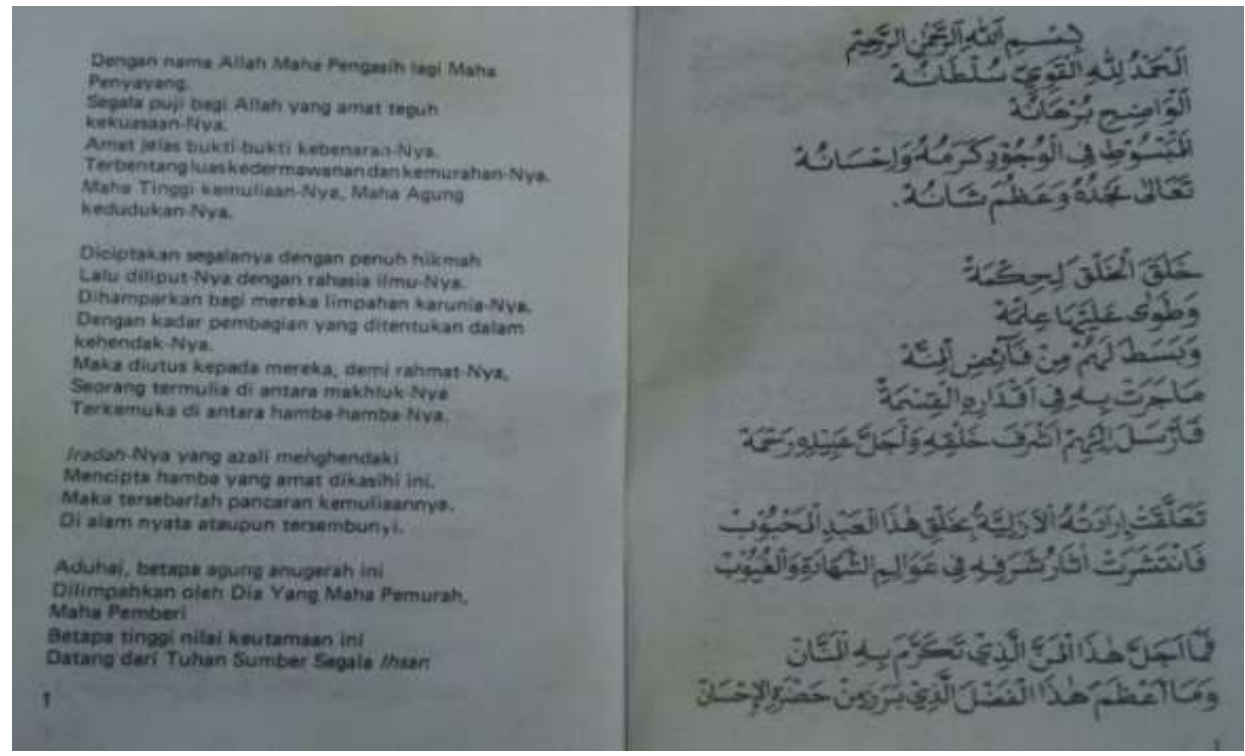

Gambar 1. Syair Kitab Maulid Al Barzanji. Sumber: Muniir, 2020

Syair-syair dalam Kitab Maulud berisi tentang doa dan dzikir yang di utamakan kepada Allah Subhanahu Wa Ta'ala dan juga berisi tentang kemuliaan akhlak Nabi Muhammad Sholalloohu Alaihi Wasallam dari kelahiran, perjuangan dakwah sampai akhir hayat Beliau. Kitab ini dibaca dengan cara para jamaah duduk bersila bersamasama sambil melantunkan syair-syair.

Zikir Hadrah ini diperkirakan muncul pada tahun 17-an di era Kerajaan Kesultanan Pontianak Kalimantan Barat. Abad 18 hingga 19-an Indonesia dijajah Belanda sehingga hal itu menyebabkan pelarangan memainkan Dzikir Hadrah. Hal tersebut dikarenakan, pada saat itu hadrah dianggap sebagai media masyarakat untuk berkumpul, sedangkan penjajah sangat melarang segala kegiatan yang mengakibatkan masyarakat dapat berkumpul. Oleh karena itu di era penjajahan, hadrah sulit untuk berkembang.

Hal yang sama terjadi saat era penjajahan Jepang pada tahun 1942-1945. Selama itu pula Jepang melarang adanya kegiatan/perkumpulan, sehingga berdampak pada kesenian Hadrah yang tidak di mainkan. Bahkan dikarenakan hal tersebut saat Indonesia merdeka, kesenian Hadrah tidak dibawakan lagi karena masuknya pasukan sekutu yang telah mengalahkan Jepang.

Sejak tahun 50-an, kesenian Hadrah ditampilkan kembali di Pontianak tepatnya di Keraton Kota Pontianak. Saat itu masih menjadi sebuah kerajaan di Pontianak dan sekarang menjadi sebuah ibu kita provinsi Kalimatan Barat.

Menurut Ust Ma'arif/ Muhammad Arif Seni Hadrah di Kota Pontianak mengalami jaman keemasan pada era tahun 60-80an. Saat itu Grup/ perkumpulan hadrah mencapai ratusan jumlahnya. Dalam satu grup Hadrah terdiri dari sekitar 50 anggota. 
Semasa hidup Sultan Abdurahman, setiap malam jumat selalu diadakan hadrah di Istana Kadriah. Kesenian ini ditampilakan secara bergiliran dari grup-grup hadrah yang ada diseluruh wilayah kota Pontianak. Masih menurut Ust Ma'arif waktu itu hampir setiap wilayah memiliki perkumpulan Hadrah. Hadrah yang dimaksud oleh beliau bukan seperti hadrah jaman sekarang yang sudah menjadi Kesenian Kreasi tetapi adalah Hadrah yang masih asli (tradisi) dimana syair-syairnya diambil dari Kitab Hadrah, syair-syair tersebut diambil dari Kitab Barzanji yang dipilih berdasar kesepakatan tokoh-tokoh hadrah waktu itu dan akhirnya dibukukan menjadi Kitab Hadrah. Tokohtokoh Hadrah dimasa itu yang merupakan guru dari Ustad Ma'arif antara lain: Ust Abdullah Ismail dari Kampung Dalam Bugis, Syarif Hamid dari Kampong Luar Tambelan, Wak lek dan H Abdul Gani dari Sungai Itik, Haji Husin Kamang dari Segedong, Setumak, Ramli, Haji Muhammad, Haji Abdurahman, Haji Muhammad Ali.

Dari tokoh-tokoh Hadrah tersebut yang paling menonjol (terkenal) adalah Haji Muhammad karena jasa beliau mengarang sebuah Syait Hadrah riwayat hidup Nabi Muhammad Saw berbahasa Indonesia. Prestasi yang diraih beliau dalam bidang seni Hadrah patut dibanggakan. Dalam event-event festival Hadrah, beliau meraih juara 1 (satu) berturut-turut selama 7 (tujuh) tahun sejak tahun 1953 yang dilaksanakan lomba tentang hadrah yang dilaksanakan di Istana Keraton Kadriyah Kota Pontianak. H. Muhammad tidak hanya tampil Hadrah di Kota Pontianak, melainkan tampil Hadrah didaerah-daerah luar Kota Pontianak. Hal ini membuatnya juga dikenal didaerah-daerah luar Kota Pontianak yaitu di desa sekitaran Wajok, Peniti, Segedong serta desa-desa yang berada di wilayah Sungai Kakap Kabupaten Kubu Raya. Mengenai sosok figurnya, beliau adalah seniman Hadrah yang tetap eksis dan melaksanakannya sesuai dengan apa yang diajarkan pada nilai-nilai yang ada di agama Islam, beliau juga merupakan seniman Hadrah sejati. Pencapaian keberhasilannya hingga H. Muhammad layak dikatakan sebagai seseorang yang berpengaruh besar pada kesenian Hadrah karena terdapat berbagai faktor yang mendukungnya, yaitu keterkaitan dan kontribusi pada pelestarian Hadrah itu sendiri serta perkembangan Hadrah yang ada di kota Pontianak, dan meletarikan serta mempekenalkan kepada masyarakat terkait budaya lokal yang ada khususnya di Kota Pontianak, (Yoga Kharisma Putra 2015).

Adapun ketiga faktor tersebut sebagai berikut:

a) adapun sumbangsih yang diberikan dalam mempertahankan Hadrah tetap terjaga sampai sekarang. H. Muhammad telah membuka lima grup Hadrah yang beberapa diantaranya adalah, Al-Hana', Hubbul Wathan, Darussurur, Darussalam dan AlMuna'. Adapun group Hadrah Hubbul Wathan masih bertahan sampai saat ini, sedangkan group Hadrah yang lainnya sudah tidak aktif lagi karena personalpersonalnya sudah banyak meninggal dunia. Disamping itu, H. Muhammad merangkul anak-anak remaja untuk dijadikan murid-murid Hadrah di Kota Pontianak dan diluar Kota Pontianak, yaitu Desa Wajok dan Desa Segedong Peniti. Dengan membentuk generasi-generasi seniman Hadrah, H. Muhammad berharap Hadrah di Kota Pontianak dapat terus dilestarikan.

b) Kontribusinya untuk perkembangan Hadrah di Kota Pontianak. Syair Hadrah riwayat hidup Nabi Muhammad Saw berbahasa Indonesia karya H. Muhammad telah memberikan kontribusinya untuk perkembangan Hadrah di Kota Pontianak. Adapun syair Hadrah riwayat hidup Nabi Muhammad Saw berbahasa Indonesia karya H. Muhammad merupakan sebuah pengembangan yang berakar dari tradisi, yaitu syair 
Hadrah riwayat hidup Nabi Muhammad Saw berbahasa Arab yang ada didalam Kitab Al-berzanji. Pengembangan tersebut dapat dilihat jelas terutama dari lirik yang digunakan didalam karya $\mathrm{H}$. Muhammad, yaitu lirik syair Hadrah berbahasa Indonesia.

c) Sumbangsih karya H. Muhammad untuk kepentingan kehidupan masyarakat Kota Pontianak. Syair riwayat hidup Nabi Muhammad Saw berbahasa Indonesia karya H. Muhammad telah memberikan sumbangsihnya untuk mempermudah orang lain dalam memahami serangkaian perjalanan hidup Nabi Muhammad Saw, mengingat bahwa tidak semua orang bisa mengerti dan memahami syair Hadrah riwayat hidup Nabi Muhammad Saw berbahasa Arab yang terdapat pada Kitab Al-berzanji. Disamping itu, syair riwayat hidup Nabi Muhammad Saw dengan bahasa Indonesia dikarang oleh $\mathrm{H}$. Muhammad tersebut dapat diterapkan untuk memeriahkan hajatan masyarakat budaya Melayu dan untuk memeriahkan acara hari-hari besar Islam di Kota Pontianak. Sampai saat ini, syair Hadrah riwayat hidup Nabi Muhammad Saw berbahasa Indonesia karya $\mathrm{H}$. Muhammad masih murni terjaga keutuhannya (orisinil) dan diakui hak ciptanya. Karyanya tersebut selalu dijadikan sebagai petunjuk bagi para seniman-seminan yang ada di Kota Pontianak yaitu kesenian Hadrah. Hal ini membuat syair Hadrah riwayat hidup Nabi Muhammad Saw yang menggunakan bahasa Indonesia karya $\mathrm{H}$. Muhammad tetap hidup, sekalipun $\mathrm{H}$. Muhammad selaku penciptanya sudah meninggal dunia.

Semua tokoh-tokoh Hadrah yang peneliti sebutkan sudah meninggal dunia (almarhum) dan sekarang diteruskan oleh Ust Ma'arif, beliau membina Hadrah Jamiatul Munawaroh (Kumpulan yang Bercahaya) dan saat ini sedang berjuang membentuk Forum Dewan Hadrah se-Kalbar untuk menghidupkan kembali Hadrah asli/tradisional di Kalbar khususnya Kota Pontianak.

Menurut Anwar Ja'far dan diperkuat keterangan dari Ust Ma'arif, pada tahun 70an kesenian Hadrah yang semula adalah dzikir dan diiringi alat musik Tar/terbang mengalami perkembangan, dibawakan dalam gerak tari yang sederhana yaitu dengan duduk bersimpuh layaknya seseorang yang sedang melakukan tahiyat awal, adapun gerakan-gerakannya terinspirasi dari goyangan ke kanan dan ke kiri orang yang sedang berzikir, kemudian terdapat juga gerakan-gerakan lain seperti gerakan mengambil wudhu (membersihkan kedua telapak tangan dan membersihkan telinga), gerakan dalam salat seperti duduk tahiyat dan takbiratul ihram, serta ada pula gerakan dalam silat yaitu kembangan/ bunga.

Ust Ma'arif menjelaskan bahwa pelopor gerak tari pengiring seni Dzikir Hadrah adalah Haji Abdul Gani dari Sungai Itik dan tarian tersebut dinamakan dengan tari Radat. Haji Muhammad, $H$ Abdurrahman dan $H$ Muhammad Ali tertarik mengembangkan tari tersebut kemudian beliau bertiga pergi bertemu Haji Abdul Gani di Sungai Itik untuk mempelajari Radat atau biasa disebut dengan Radat dan mengembangkan tari tersebut di perkumpulan Hadrah di sekitar Sungai Jawi tepatnya di Jalan Suwignyo Masjid Syakirin. Perkumpulan tersebut bernama Darussurur yang sekarang berubah nama menjadi Hubbul Wathan dan eksis mengembangkan Kesenian Hadrah di Kota Pontianak.

Grup Hadrah pertama adalah Hubbul Wathan yang bermarkas di Jl. Suwignyo Gang Nur 4, yaitu dirumah bapak Awwaludin yang sekaligus menjadi pemimpin grup Hadrah ini, grup ini sudah berjalan selama 60 tahunan, yang sebelumnya bernama 
Darussurur yang dipimpin oleh H. Muhammad dan berproses berganti nama Al-Hana yang dipimpin oleh Hamdan AS, dan saat sekarang berubah nama menjadi Hubbul Wathan yang dipimpin oleh Awaluddin yang juga merupakan pembawa Takhtim.

Kesenian Hadrah yang ada di Kota Pontianak dan sekitarnya merupakan buah hasil dari keterkaitan dan dukungan baik secara individu orang tua serta kesukaan terhadap seni ini, sehingga tetap berjaya walaupun sudah berada di era modern sekarang ini. Salah satunya adalah Grup Hadrah Hubbul Wathan yang sudah menjadi lembaga resmi yaitu pada tanggal 31 Desember tahun 2015, yang diketuai oleh bapak Awaluddin, bapak Abdur Rahman yang bertindak sebagai sekretatis serta bapak Muchlisin sebagai bendahara, hal dilalukan adalah salah satu upaya agar grup Hadrah ini sudah berlabel hukum, sehingga dapat mengembangkan sayapnya apabila diundang untuk mengisi acara di kantor-kantor dan instansi-instansi pemerintah.

Menurut Anwar Djafar dan Ust Ma'arif tahun 1980 Seni Dzikir Hadrah sudah berubah menjadi Kesenian Kreasi, dimana alat musik mengalami perubahan yang tadinya hanya Tar/Terbang/Rebana mengalami penambahan Bedug kecil, Darbuka, Tamborin dan bahkan dalam Kesenian Hadrah modern menggunakan Keyboard. Lagulagu yang dimainkan tidak hanya diambil dari Syair-syair dari Kitab Hadrah akan tetapi juga memainkan lagu-lagu Marawis, Jepin, Nasyid, Kasidah.

Bentuk penyajian kesenian Hadrah sekarang sudah mengalami perubahan. Seiring perkembangan zaman yang dahulunya seni tarian tersebut merupakan alat atau media yang tujuannya adalah untuk misi penyebaran bagi agama Islam dan juga beribadah, berubah menjadi seni pertunjukan yang kemudian ditandingkan atau diperlombakan. Kesenian Hadrah yang dulunya hanya berupa lantunan syair-syair saja berkembang dan ditambahkan gerakan-gerakan di dalamnya. Gerakan dalam kesenian Hadrah dinamai dengan Radat, sehingga masyarakat sekira sering menyebutnya dengan tari Radat dan pelaku atau pemainnya dinamai Peradat.

Tari Radat dalam kesenian Hadrah selalu disesuaikan bentuk penyajiannya dalam setiap kondisi atau penyajiannya. Apabila dibawakan dalam acara keraton atau dipertontonkan kepada Raja maka pola lantai, durasi serta syairnya disesuaikan.

Pada acara keistanahan maka akan di sajikan kepada Raja dan para tamunya di teras Keraton Kadriah Pontianak, (Wibowo, Kusnoto, and Syaifulloh 2014). Guna memberikan hiburan bagi para tamu-tamu yang diundang oleh raja atau sultan tidak sembarang group yang bisa tampil. Group-group ini ditunjuk langsung oleh Raja. Semasa kejayaan Sultan Muhammad group yang sering ditunjuk oleh beliau satu diantaranya adalah Group dari Hubbul Whatan yang dulunya bernama Darus Surur dan dipimpin oleh Almarhum H. Muhammad Bin Muhammad Noer dan sekarang group ini dipimpin oleh Bapak Awaluddin Hamdan cucu dari H. Muhammad. Berikut ini adalah pola lantai pemain Hadrah serta posisi Raja dan Tamunya pada penyajian Kesenian Hadrah yang di bawakan untuk acara di Keraton Kadriah. 


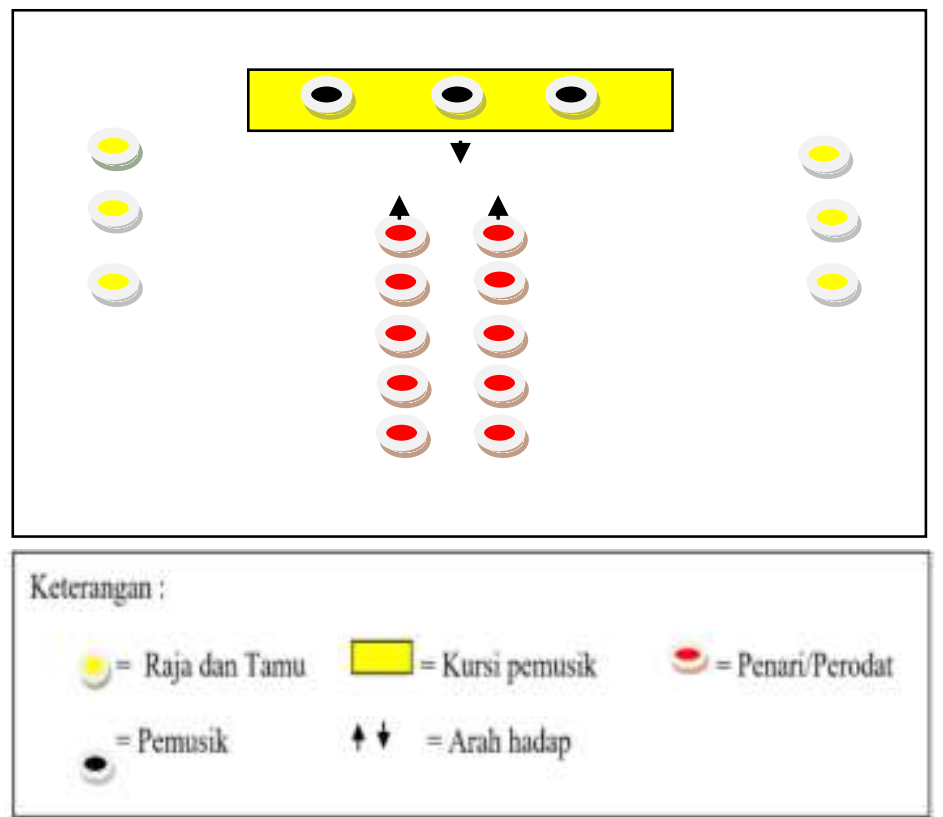

Gambar 2. Pola tari Radat untuk di Istana (Nurbaiti, 2016)

Para penari dan penabuh memposisikan diri berada di tengah ruang teras Istana Kadriah. Posisi duduk raja dan tamunya berada di samping para pemain Hadrah. Pola lantai yang digunakan adalah pola lantai vertikal membentuk 2 bersab ke belakang untuk peradat, sedangkan pemusiknya sejajar membentuk horizontal. Para pemusik dan peradat saling berhadapan. Kedudukan pemusik sedikit lebih tinggi dari peRadat. Dengan menggunakan kursi panjang yang dilapisi kain berwarna kuning. Adapun disetiap sudut keraton di beri dupa sebagai pengharum.

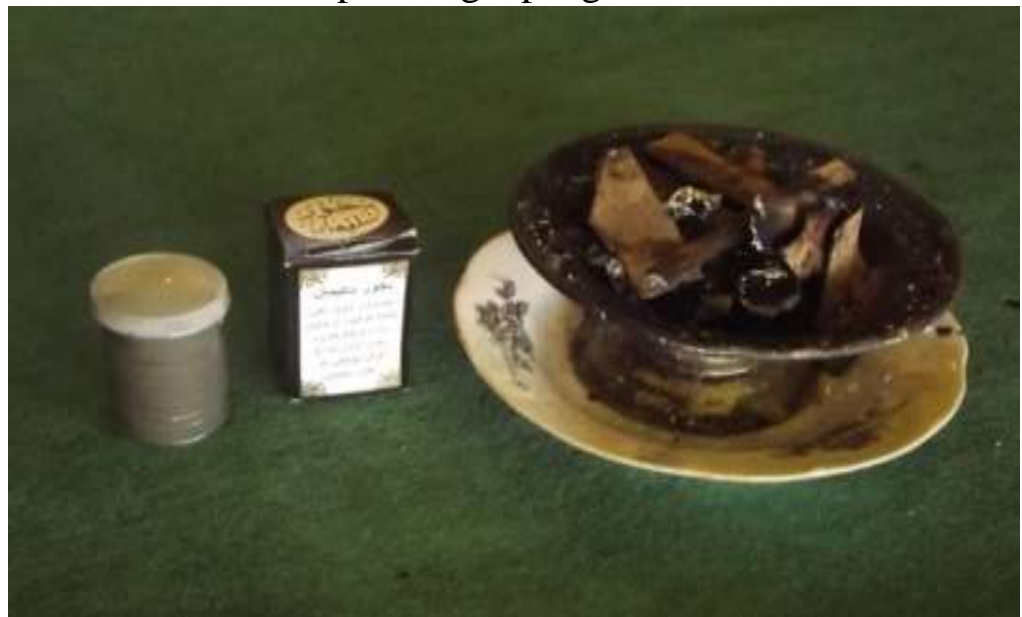

Gambar 3. Foto dupa yang dicampur arang (Nurbaiti, 2016)

Kesenian Hadrah juga dibawakan pada acara hajatan oleh masyarakat di kota Pontianak. Bentuk penyajian, khususnya pada pola lantainya juga mengalami penyesuaikan. Berikut ini merupakan contoh gambar pola lantai pada kesenian Hadrah yang di tampilkan pada acara hajatan di rumah masyarakat. 


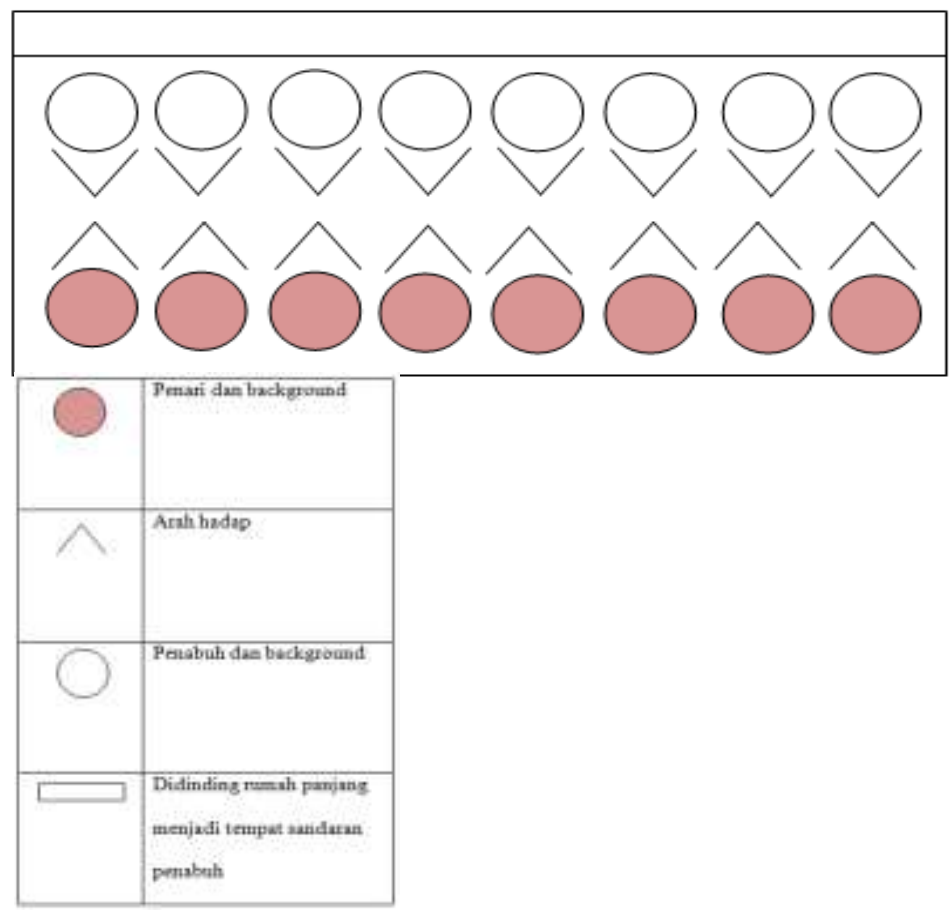

Gambar 4. Pola tari Radat untuk acara hajatan masyarakat Pontianak (Tindarika, 2020)

Berdasarkan gambar tersebut dapat dilihat bahwa tempat pertunjukan kesenian hadrah ini dahulunya berada di selasar rumah panjang dengan posisi para pemain duduk saling berhadapan. Penabuh ini akan berganti-ganti secara bergiliran mulai dari pemain pertam ke pemain yang selanjutnya sesuai dengan penanda pergantian tersebut adalah dengan berhentinya lantunan syair dan para pemain bertepuk tepuk selama kurang lebih 5 detik. Para pemain yang bertugas sebagai penari (tari Radat) ini sesekali melakukan gerakan berlutut dan bersimpuh yang biasa disebut dengan tumbuk alok.

Menjelang Bulan Rabiul Awal (bertepatan bulan Oktober 2020) yang merupakan bulan Kelahiran Nabi Muhammad SAW, kelompok-kelompok Kesenian Hadrah di Kota Pontianak mulai latihan lagi. Dan saat ini Kesenian Hadrah mulai tampil lagi untuk mengisi acara-acara Maulid Nabi maupun acara-acara yang lain. Berikut ini adalah contoh gerakan Tari Radat yang dibawakan grup Hadrah Hubbul Wathan pada saat acara pernikahan.

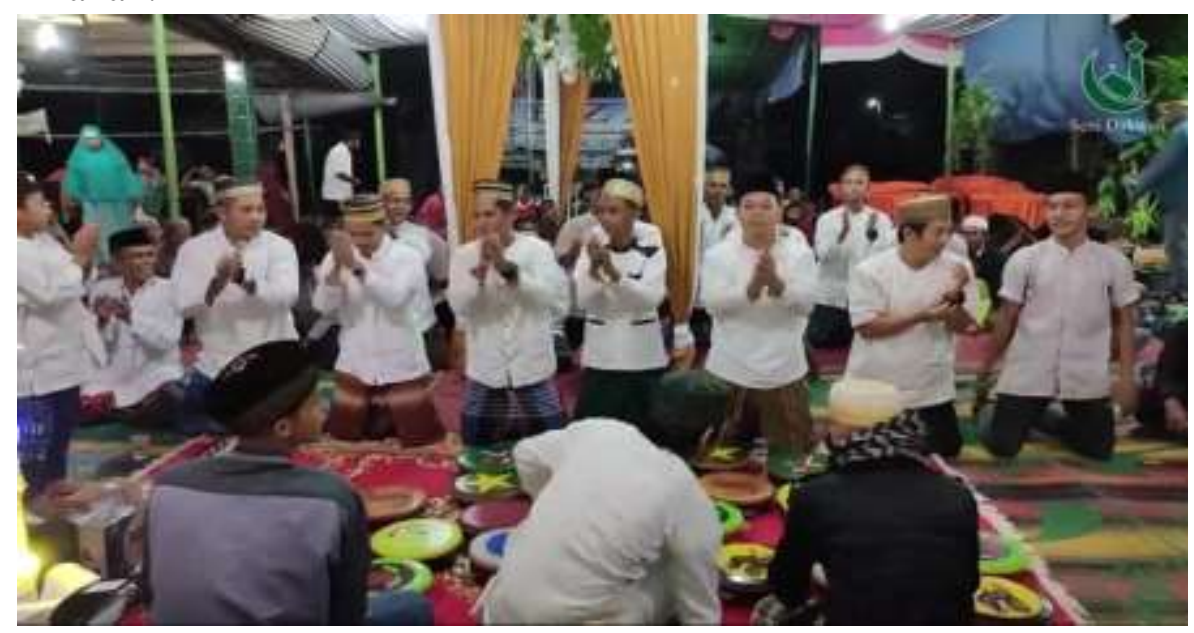


Gambar 5. Gerakan berdiri bertumpu pada lutut sambil bertepuk tangan (Muniir, 2020)

Kesenian Hadrah ini dilaksanakan dengan cara para penabuh menghadap ke arah penonton. Adapun yang tadinya penabuh saling berhadapan kemudian posisi mereka berubah menjadi 2 bershaf yang menghadap ke penonton.
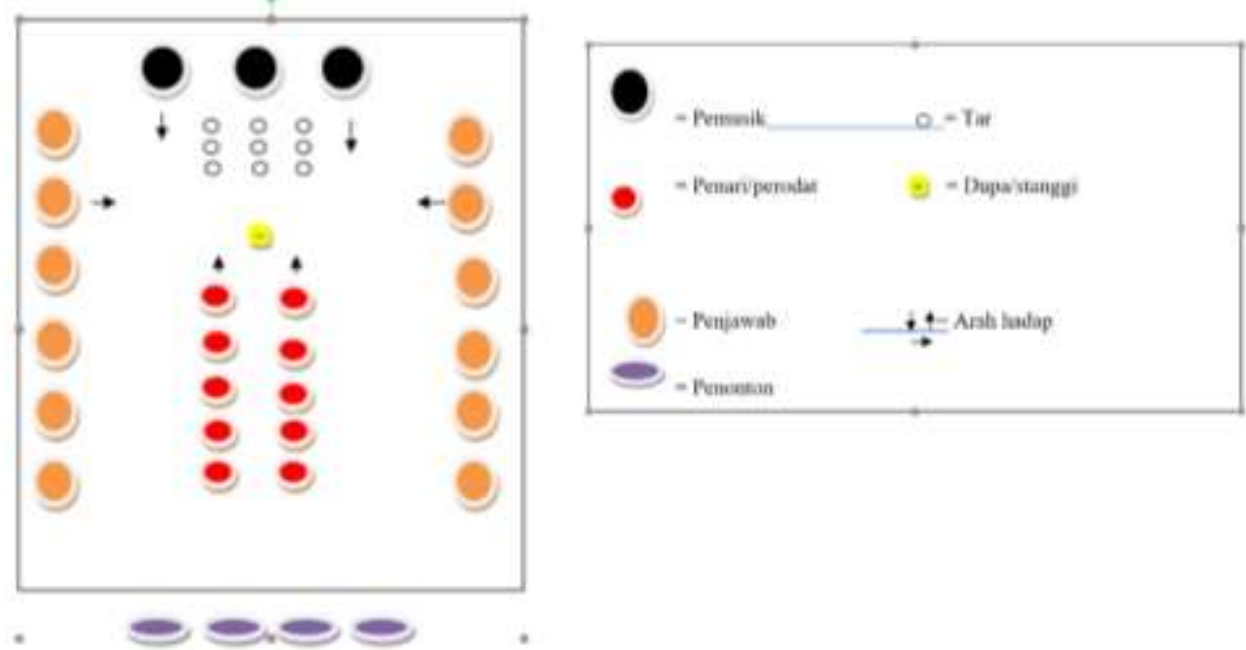

Gambar 6. Pola tari Radat untuk hajatan (Nurbaiti, 2016)

Pada saat ini gerakan-gerakan penari mengalami perkembangan, sudah sangat bervariasi membentuk formasi-formasi yang indah sambil berdiri dan tarian tersebut tidak bernama Radat tapi Tari Kreasi Pengiring Hadrah. Para Penari terkadang membawa properti-properti tertentu untuk memperindah gerakan mereka. Bila dibawakan untuk dipertunjukan atau perlombaan maka penari yang tadinya saling berhadapan kemudian mengalami penyesuaian yaitu menghadap ke hadapan penonton. Bila dikaji berdasarkan pendapat (Hadi 2017), bahwa arah hadap penari perlu mempertimbangkan panggung atau stage. Apabila menggunakan panggung prosenium maka harus mempertimbangkan penonton yang hanya berada pada satu arah saja. Menurut (Soedarsono 2010), fungsi seni pertunjukan adalah sebagai sarana ritual atau upacara keagamaan, hiburan pribadi dan presentasi estetis atau dipertontonkan. Sejalan dengan pendapat tersebut, kesenian Hadrah desawa ini berfungsi juga sebagai sajian yang di pertontonkan.

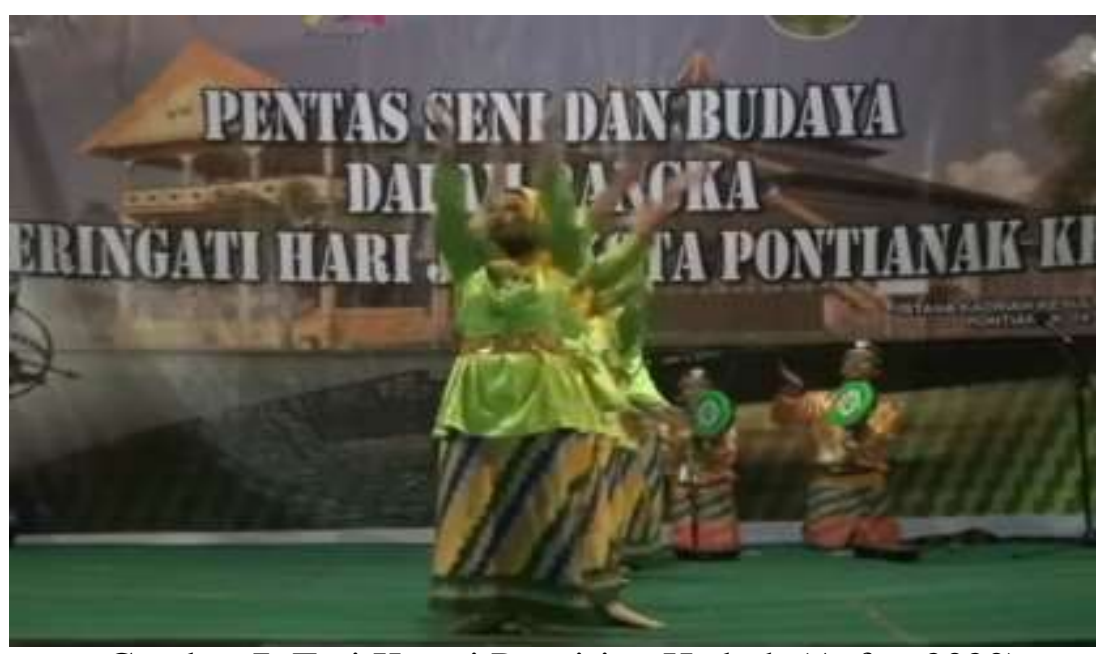

Gambar 7. Tari Kreasi Pengiring Hadrah (Asfar, 2020) 
Perubahan juga terjadi di pada segi kostum yang mana pada zaman dahulu para penabuh ini menggunakan baju busana muslim yaitu baju koko akan tetapi pada tahun 1955 baju yang dikenakan oleh penabuh diubah menjadi baju adat Melayu yaitu terdiri dari baju kurung dan kain corak insang hal ini dikarenakan karena kesenian ini Ini dibawa ke hadapan kerajaan Melayu Pontianak sehingga pakaian yang dikenakan juga turut disesuaikan. Pada tahun 70an baju yang dikenakan oleh para penabuh ini adalah baju kurung kain corak insang dan wajib berkerudung bagi wanita sedangkan bagi penabuh pria yang dikenakan adalah baju adat Melayu Yaitu terdiri dari baju Teluk belanga kain corak insang dan juga kopiah.

Alat musik yang dipakai pada kesenian hadrah pada saat ini mengalami perkembangan dan variasi yang beragam, akan tetapi ada satu alat musik inti yang harus ada dalam Kesenian Hadrah yaitu Tar, ada yang menyebutnya Terbang. Menurut Ust Ma'arif asal kata Tar (dalam bahasa Indonesia berarti terbang) adalah pada jaman dahulu di Masjidil Haram Kota Mekah ada seorang Auliya (kekasih Allah) bernama Habib Abubakar bin Abdullah al Idrus, beliau senang memainkan alat musik pukul di teras masjid sambil berdzikir Lailaahaillallah diulang- ulang terus dengan suara yang merdu mengikuti pukulan alat musik tersebut. Didalam masjid ada ulama (orang pandai dalam ilmu agama Islam) sedang menulis buku fikih, beliau terganggu dengan bunyi alat musik pukul yang dimainkan Habib Abubakar, maka beliau keluar masjid menegur dan mengatakan bahwa perbuatan berdzikir sambil bermain alat music tersebut adalah perbuatan mungkar (bedosa).

Habib Abubakar menjawab kalau ini mungkar maka saksikanlah, tolong engkau pegang alat musik ini saya akan berdzikir tanpa alat musik dan tolong engkau cukup memegangnya saja, maka mulailah $\mathrm{Hb}$ Abubakar berdzikir Lailaahaillallah dengan suara yang indah sambil tawaf mengelilingi Kakbah, tanpa disadar ulama yang diminta memegang alat musik pukul tadi itu memainkan memainkan alat musik tersebut mengiringi lafaz dzikir yang dilantunkan Habib Abubakar maka Habib Abubakar berkata, "Lihatlah engkaupun tidak bisa menahan untuk tidak memainkan alat musik tersebut, kesadaranmu 'terbang' (dalam bahasa Arab terbang = tar) ". Hingga sekarang berdasar dari riwayat tersebut maka alat musik pukul yang dipakai Habib Abubakar untuk mengiringi dzikir Beliau disebut Tar / Terbang.

Dalam Kesenian Hadrah alat musik Tar yang dipakai ada 3 dengan setelan (stem) sama yaitu : Tar nginduk, Tar nganak dan tar ningkak, ada yang menyebutnya Tar Induk, Tar anak 1 dan tar anak 2, ada juga yang menyebutnya Tar 1 , Tar 2 dan Tar 3. Ada 2 warna bunyi dalam permainan alat musik Tar yaitu "dung" dan "cang", (Rahman 2018). Gambar berikut adalah posisi tangan kanan sebagai pemukul/menabuh untuk menimbulkan warna bunyi "Dung" dan "Cang : 


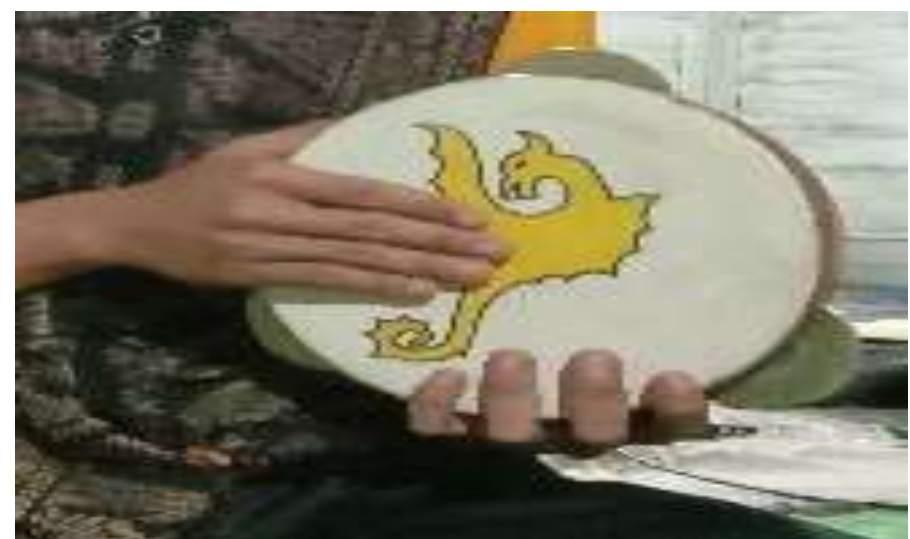

Gambar 8. Warna bunyi "Dung" (Asfar, 2020)

Gambar di atas menjelaskan bahwa empat jari ditangan kanan dimulai dengan jari telunjuk yang merupakan diletakkan jari paling atas, jari tengah, jari manis, jari kelingking dan sebagian telapak tangan digunakan untuk memukul Tar dibagian tengah sehingga menghasilkan warna bunyi "Dung" pada Tar/ Terbang.

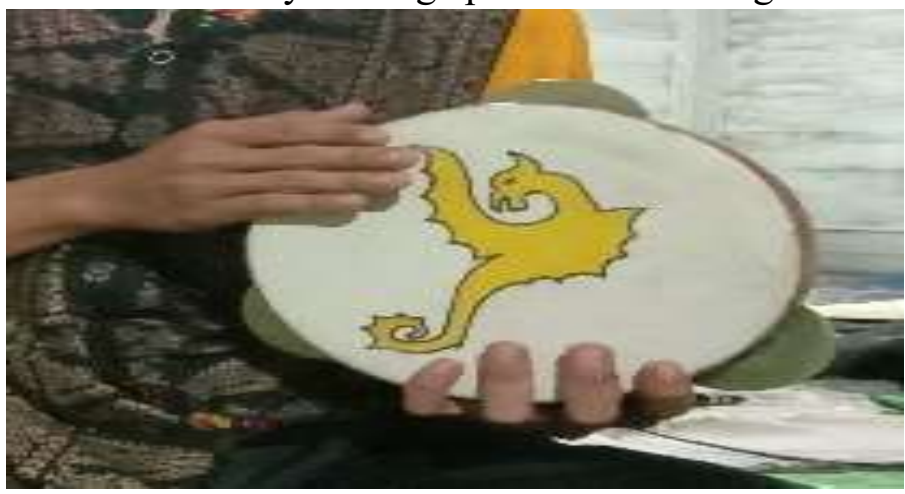

Gambar 9. Warna bunyi "Cang"

Gambar 9 menjelaskan bahwa empat jari ditangan kanan dimulai dengan jari telunjuk paling atas, diikuti jari tengah, selanjutnya jari manis, dan yang terakhir adalah jari kelingking digunakan untuk memukul. Tar dibagian tepi pada kulit, sehingga menghasilkan warna bunyi "Cang" pada Tar. Dari kedua warna bunyi yang ada pada Tar, teknik memukul untuk menghasilkan warna bunyi "Dung" dan "Cang" haruslah sesuai dan dengan benar, jika letak posisi jari tersebut dengan benar dan sesuai, jika posisi dari jari yang diletakkan tidak benar dan sesuai maka suara atau bunyi yang dihasilkan tidak akan sempurna.

Urutan penyajian Kesenian Hadrah dalam suatu acara dapat dijabarkan selengkapnya :

1. Diawali dengan membaca Surat Al Fatihah untuk baginda Rosululloh SAW,

2. Membaca Sholawat pembuka oleh Imam/ pemimpin kemudian jamaah mengulangi bacaan pemimpin, contoh:

Pemimpin: Yaa Robbi Sholli 'Alaa Muhammad Yaa Robbi Sholli 'Alaihi wasalliiim Jamaah: $\quad$ Yaa Robbi Sholli 'Alaa Muhammad Yaa Robbi Sholli 'Alaihi wasalliiim Pembacaan Sholawat pembuka tanpa iringan musik (Dzikir Hadrah) diambil dari Kitab Maulud Al Barzanji

3. Setelah Sholawat pembuka, mulailah Pembukaan Hadrah (Seni Hadrah dengan iringan musik) dengan membawakan syair Sholatulloh dengan iringan Tar. 
4. Setelah Pembukaan Hadrah menurut Ust Ma'arif, "Aturannya tuan rumah harus ikut membawakan Syair Hadrah karena tuan rumah yang punya hajat dan filosofinya supaya hajat tuan rumah terkabul maka harus ikut membawakan syair tersebut, kalau tuan rumah tidak bisa harus mewakilkan orang lain yang membawakan, itu tradisi sesungguhmya." kata beliau.

5. Setelah tuan rumah jamaah yang hadir/ dipanggil datang membawakan Syair Hadrah bersama-sama dengan iringan Terbang/ Tar.

6. Kalau tuan rumah menghendaki Asrakal maka dibawakan syair Asrakal dari kitab Al Barzanji, jamaah membawakannya dengan berdiri atau yang sering disebut Mahalul Qiyam.

7. Setelah Asrakal semua jamaah duduk kembali kemudian membawakan Syair Tahtim sebagai penutup.

8. Yang terakhir Penyajian Kesenian Hadrah ditutup dengan doa yang diambil dari Kitab Maulud Al Barzanji.

Fungsi Kesenian Hadrah yang tadinya sebagai sarana dakwah pengiring Dzikir Hadrah dan hanya dimainkan saat Maulud Nabi sekarang berubah menjadi fungsi hiburan dimainkan pada banyak acara, seperti: pernikahan, aqiqah/ gunting rambut, khitanan, peresmian kantor baru, hajatan pengajian dan juga pada acara bayar nadzar, (Tindarika 2021).

Anwar Djafar yang merupakan anggota dari Grup Hadrah Hubbul Wathan mengatakan bahwa Kesenian Hadrah di Kota Pontianak masih tetap eksis sampai sekarang terbukti dari banyaknya perkumpulan-perkumpulan Hadrah di Kota Pontianak. Grup-grup tersebut aktif mengikuti kompetisi festival Kesenian Hadrah yang diadakan rutin setahun sekali pada saat ulang tahun Kota Pontianak. Penyelenggara acara tersebut adalah MABM (Majelis Adat Budaya Melayu).

Khusus untuk tahun 2020 kegiatan tersebut ditiadakan karena saat ini dunia khususnya kota Pontianak sedang dilanda wabah penyakit/pandemi Covid 19. Anwar Djafar menjelaskan pula, pada Bulan April 2020 semua grup hadrah berhenti latihan (vakum sementara) dikarenakan adanya larangan dari Pemerintah Kota untuk berkumpul dikarenakan wabah virus Corona yang sedang melanda, dan Pontianak beberapa kali menjadi wilayah dengan zona merah. Untuk memutus rantai penularan virus tersebut pemerintah menghimbau untuk tetap di rumah, bahkan kegiatan belajar dan pembelajaran dialih tempat dan sarana, yaitu belajar di rumah masing-masing dan menggunakan aplikasi pendukung.

Hal tersebut berdampak pada kegiatan berkesenian di Kota Pontianak. Grupgrup Kesenian Hadrah berhenti latihan bahkan tidak tampil untuk sementara. Hal tersebut dikarenakan pemerintah melarang mengadakan acara yang melibatkan banyak orang atau tidak memperbolehkan adanya kegiatan mengakibatkan masyarakat berkumpul. Semua kebijakan tersebut diambil pemerintah untuk mencegah penularan virus Corona di masyarakat. Demi kesehatan dan keselamatan bersama masyarakat khususnya seniman Hadrah ikut melaksanakan himbauan dari pemerintah tersebut. 


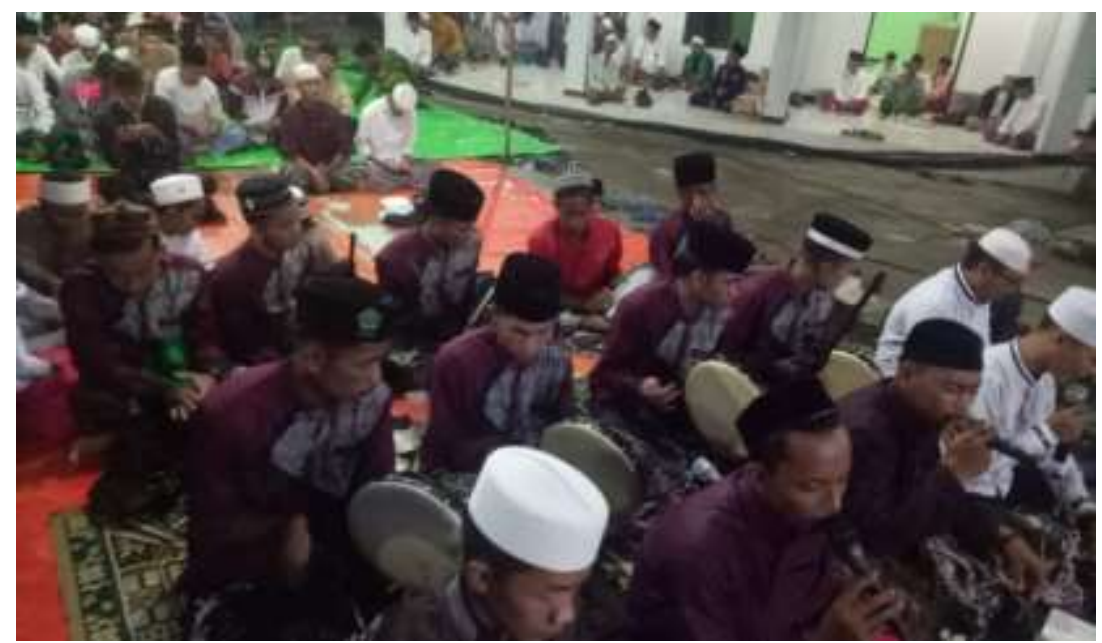

Gambar 10. Grup Hadrah Al Amin pada acara Maulid Nabi Muhammad SAW

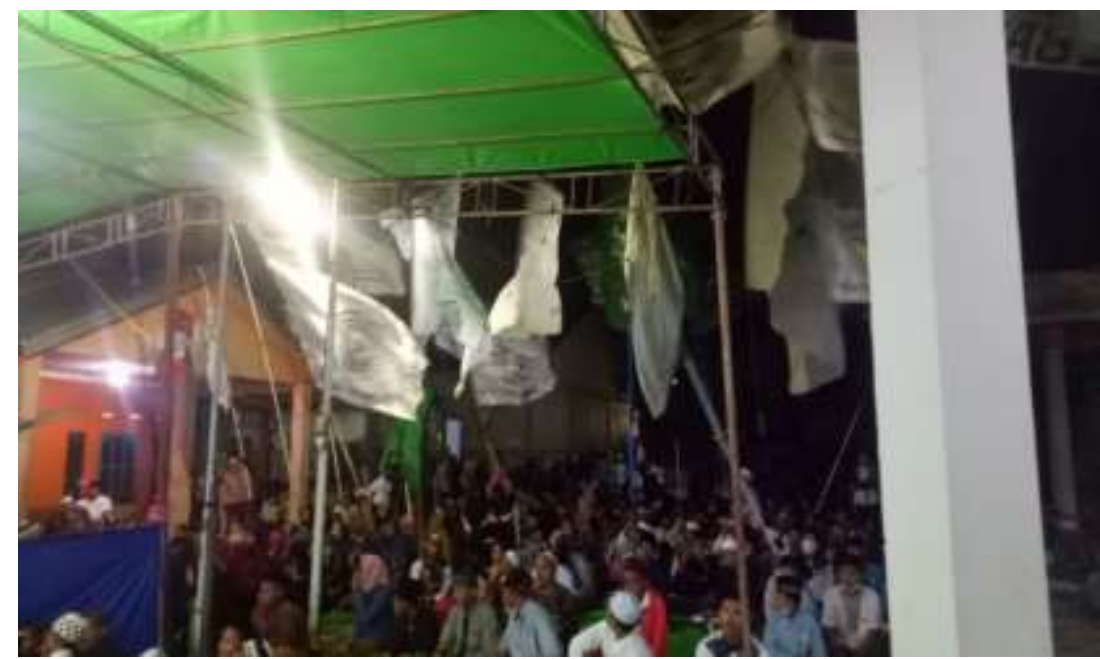

Gambar 11. Properti bendera pada acara Maulid Nabi di jalan Perdamaian Pontianak

Menjelang Bulan Rabiul Awal (bertepatan bulan Oktober 2020) yang merupakan bulan Kelahiran Nabi Muhammad SAW, kelompok-kelompok Kesenian Hadrah di Kota Pontianak mulai latihan lagi. Sampai saat ini Kesenian Hadrah mulai tampil dan eksis lagi untuk mengisi acara-acara Maulid Nabi maupun acara-acara yang lain.

\section{PENUTUP}

Berdasarkan penjabaran di atas dapat diketahui perjalanan kesenian Hadrah dari awal muncul di kota Pontianak hingga mampu bertahan hingga sekarang. Seiring berkembangan zaman, kesenian Hadrah yang awalnya berfungsi sebagai penyebaran agama Islam oleh para pedagang yang berasal dari Yaman dan para alim ulama, berkembang menjadi seni pertunjukan. Hadrah muncul karena proses akulturasi antara kebudayaan pendatang (Yaman) dengan kebudayaan asli yang dimiliki oleh masyarakat kota Pontianak dan menjadi menjadi warisan budaya yang masih di lestarikan hingga sekarang. Hadrah mengalami berbagai macam penyesuaian dalam perkembangannya. Hal tersebut tergambar saat dibawakan dalam kalangan kraton Kadriah. Maka posisi 
pemain, Raja dan para tamu undangan disesuaikan pula. Begitu juga saat dibawakan dalam hajatan yang diadakan oleh masyarakat dan juga diperlombakan dalam ajang festival. Perkembangan juga terjadi pada alat musik, syair dan pola tabuhannya. Walaupun telah banyak kesenian-kesenian lain lahir dan berkembang. Kesenian Hadrah masih terus dipertahankan oleh pada masyarakat Kota Pontianak dan sekitarnya, dengan dibuktikan masih terdapat grup Hadrah yang masih eksis walaupun di era modern seperti sekarang ini, dengan demikian masih banyak pula masyarakat yang sadar akan kesenian budaya ini, serta kesenian tradisi ini menjadi salah satu budaya yang mereka miliki. Serta nilai yang terkandung pada kesenian tersebut masih melekat dihati masyarakat kota Pontianak.

Saran yang diberikan pada riset ini yaitu kepada pihak-pihak terkait dalam penelitian ini, diantaranya: kepada lembaga-lembaga pemerintah dan kebudayaan KalBar untuk terus memperhatikan kesenian tradisi yang dimiliki. Bentuk perhatian itu bisa berupa bantuan kepada para seniman dan grup Hadrah yang masih bertahan hingga sekarang, sehingga kesenian ini tetap dapat hidup dan bertahan. Untuk masyarakat kota Pontianak, khususnya para generasi muda untuk terus aktif dan dapat mempertahankan kesenian tradisi yang dimiliki. Untuk seluruh pihak dapat mengapresiasi kesenian tradisi khususnya Hadrah, sehingga Hadrah dapat terus diwariskan hingga cucu dan cicit kita.

\section{DAFTAR PUSTAKA}

Ary, Donal, Luchy Cheser Jacobs, Asghar Razavieh. 2011. Pengantar Penelitian Dalam Pendidikan. Diterjemahkan oleh Arief Furchan. Yogyakarta: Pustaka Pelajar.

Batubara, Santy Mayda. 2017. "Kearifan Lokal Dalam Budaya Daerah Kalimantan Barat (Etnis Melayu Dan Dayak).” Jurnal Penelitian IPTEKS 91-104.

Daud, Muhammad Zaid, Mohammad Shahrul, and Nizam Abd. 2019. "Sains Humanika Hadrah 's Performances in Sarawak: An Ethnography Communication Approach Persembahan Hadrah Di Sarawak: Pendekatan Etnografi Komunikasi." 2(May):47-55.

Djamal, M. 2015. Paradigma Penelitian Kualitatif. Jogjakarta: Pustaka Pelajar.

Hadi, Sumandiyo. 2017. Koreografi Bentuk-Teknik-Isi. Yogyakarta: Cipta Media.

Hemafitria, and Yuliananingsih. 2020. "Peran Majelis Adat Budaya Melayu Dalam Penanaman Nilai- Nilai Kemanusiaan (Human Values) Di Kota Pontianak." Jurnal Pendidikan Kewarganegaraan 4(1):36. doi: 10.31571/pkn.v4i1.1723.

Jazuli, M. 2014. Sosiologi Seni; Pengantar Dan Model Studi Seni Edisi 2. ogyakarta: Graha Ilmu.

Koentjaraningrat. 2015. Pengantar Ilmu Antropologi. Jakarta: Rineka Cipta.

Madjid, M. Dien. 2018. "Relasi Budaya Arab-Melayu Dalam Sejarah Di Indonesia." Buletin Al-Turas 19(2):435-52. doi: 10.15408/bat.v19i2.3729. 
Meri, La (Diterjemahkan oleh Soedarsono). 1986. Komposisi Tari, Elemen-Elemen Dasar. Yogyakarta: Lagaligo.

Nurmansyah, Gunsu, Nunung Rodliyah, Recca Ayu Hapsari. 2019. Pengantar Antropologi Sebuah Ikhtisar Mengenal Antropologi. Bandar Lampung: Anugrah Utama Raharja.

Rahman, Nur. 2018. "Fungsi Musik Kesenian Hadrah Di Desa Seuduk Kecamatan Sejangkung Kabupaten Sambas." Pendidikan Dan Pembelajaran Khatulistiwa.

Soedarsono. 2010. Seni Pertunjukan Indonesia Di Era Globalisasi. Yogyakarta: Gajah Mada University Press.

Sugiyono. 2009. Memahami Penelitian Kualitatif. Bandung: Alfabeta.

Sugiyono. 2015. Metode Penelitian Kombinasi (Mix Methods). Bandung: Alfabeta.

Sugiyono. 2018. Metode Penelitian Kuantitatif Kualitatif Dan R\&D. Bandung: Alfabeta.

Tindarika, Regaria. 2021. "Nilai-Nilai Dalam Kesenian Hadrah Di Kota Pontianak." Jurnal Pendidikan Sosiologi Dan Humaniora 12(1):1. doi: 10.26418/jpsh.v12i1.46319.

Wibowo, Basuki, Yuver Kusnoto, and Muhammad Syaifulloh. 2014. "PONTIANAK KALIMANTAN BARAT Keuangan Pusat Dan Daerah Dalam Kerangka Negara Kesatuan Republik Dasar, Dimana Salah Satu Hak Dasar Adalah Hak Untuk Memiliki Dan Mengelola.” Jurnal Edukasi 1(1):11-27.

Yoga Kharisma Putra. 2015. "Biografi H. Muhammad (Tokoh Seniman Hadrah Kota Pontianak)." Pendidikan Dan Pembelajaran Khatulistiwa 1-12. 
AKSARA: Jurnal Ilmu Pendidikan Nonformal

P-ISSN 2407-8018 E-ISSN 2721-7310 DOI prefix 10.37905

Volume 07, Issue 03 September 2021

http://ejurnal.pps.ung.ac.id/index.php/Aksara 